\title{
NEW AGE TOURISM PRODUCT: THE CRUISE INDUSTRY - THE FASTEST GROWING TOURISM SECTOR
}

\section{Paramita Suklabaidya*}

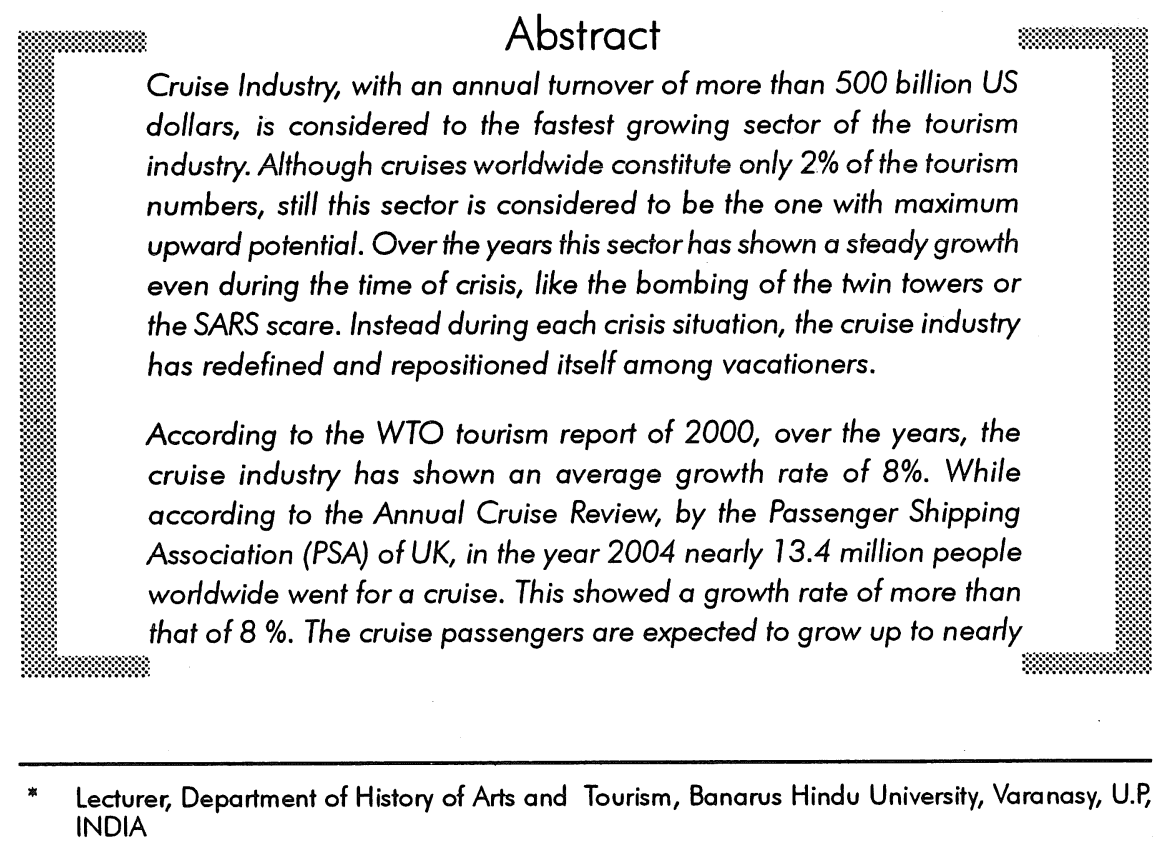


15 million by the year 2006 and 20 million by the year 2012. This is a huge number but unfortunately the Indian Coastline is not witnessing the same growth rate as the rest of the world. The full potential of the cruise industry has not been explored properly in India. The Ministry of Tourism has awakened to this relatively new tourism product in India and efforts are on to finalize a cruise policy with the collaboration of both the Ministry of Tourism and the Ministry of Shipping.

This paper is an attempt to understand Cruise Industry, specially cruise as a tourism product and find the reasons for its growing popularity worldwide. The Indian cruise scenario and the scope of this sector in Indian context will also be looked into.

\section{Introduction: The Modern Cruise Industry}

The cruise industry has emerged as one of the fastest and steady growing segment of the tourism industry. Over the years the cruise industry has maintained an average growth rate of $8 \%$. The passenger numbers have expanded from nearly 4.4 million in the early nineties to an estimated 13.4 million passengers in the year 2004 (Annual Cruise Review 2004). An estimated 13.6 million passengers are expected to take cruise vacation in the year 2005 (Ocean Shipping Consultants, UK). The Annual Cruise Review, Ocean Shipping Consultants and CLIA (Cruise Liners International Association), all expect the passengers to growunto 20 million by the year 2012 .

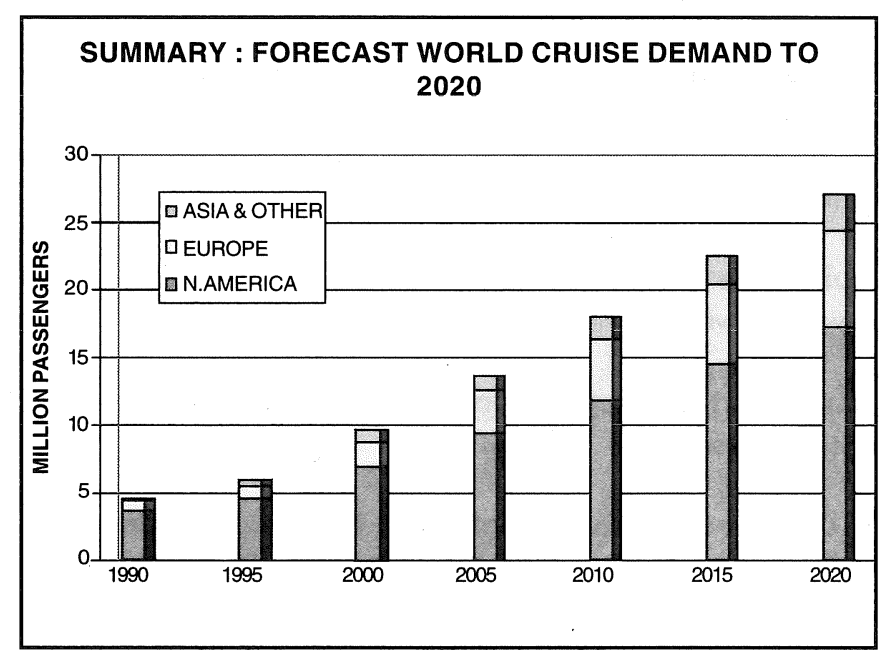

Source: http://www.osclimited.com/releases 
No doubt this is the segment worthy of taking notice. After all, the increase in the passenger numbers is always reflected in the world economics. Moreover, the modern cruise industry with an annual turnover of 500 billion US dollars cruise industry (www.tn.nic.in) is very different from the transatlantic voyages of the yesteryears.

The concept of cruising can be better understood if we classify the different types of cruises available in the market. The classification of the cruise industry here is based on the route taken by the ships. Thus the industry can be classified as: -

1. The Ocean Liners: An Ocean liner is an ocean going passenger vessel that runs over a fixed route on a fixed schedule. (David. W. Howel). It is for pointto-point destination.

2. The Cruise Liners: Cruise Liners are luxury ships with more than one port on its itinerary and at times with no port of call, also known as cruise to nowhere. It is a travel by ship for enjoyment.

3. Coastal Cruise: The cruises where the ship never loses the sight of the coast. These kinds of cruises are possible along the coasts with changing scenery after every few meters. E.g. Alaskan Cruise

4. Freighters: Cargo liner and Freighter are interchangeable terms. A vessel Primarily engaged in transporting the goods, which is licensed to carry a maximum of 12 passengers.

5. River Cruise / Canal Cruise: The big boats and smaller ships, which move from one destination to another on the major rivers of the world. E.g. River Rhine, Nile, Mississippi and others. The canals are the canals, which are found in the city of Venice, Italy and France.

6. Lake Cruise: The houseboats and lake cruise on hourly basis in some major lakes as well as wild life sanctuaries.

7. Ferry: It is a short distance crossing with informal seating and deck space. (Norma P. Nickerson)

Other luxury boats such as Yachts, Sailboats, Bare Boat charters, Houseboats, Submarines, Canoes and Hovercrafts are also part of this segment of leisure industry. In this paper the focus is especially on the coastal cruises and cruise liners - also known as the floating cities. 


\section{Reasons for the Worldwide Popularity}

The growth rate in the demand of the cruise liners is showing a steady upward mobility. According to PSA, the UK cruise industry grew by $16.6 \%$ in the year 2003 over 2002. In the year 2003 the passengers traveling by CLIA ships increased by almost $9 \%$ over 2002 (CLIA reports). Annual cruise review, by Cruise UK, shows an increase by $8 \%$ in the overall Cruise Industry in UK in the year 2004. While in the same year, the North American source market saw an increase of bookings by $8 \%$. The annual cruise review 2004 states that:

- worldwide cruise passenger numbers grew by $8.4 \%$ to 13.4 million in a year.

- passengers would reach 15 million worldwide in 2006 and 20 million in 2012.

- largest source North America showed an increase of $8.5 \%$ and bookings reached 8.9 million.

- in 2005, North American bookings should go up to 9.4 million up by $5.6 \%$.

According to CLIA, the overall increase for the first three quarters of the year 2005 show a $5.7 \%$ increase in the worldwide passengers to 8.35 million passengers, up from 7.90 million passengers for the same period in 2004 . The continuous steady growth in the demand for cruise vacations makes it a matter of research, io find out and understand the growth factors. And if possible incorporate them in the other sectors of the tourism industry.

According to Davidoff, there are five specific appeal of cruise to the travelers:

1. The passengers have the opportunity to visit a variety of destination in a short period of time without the hassle of other modes of travel.

2. Ships are self - contained.

3. Cruise ships have a cruise director with an entire staff whose sole function is to make sure that the passengers are having a good time.

4. High quality of food is served in an elegant style, and

5. Everyone usually begins and ends their vacation the same day.

Other than the above, there are few other facts that affect the way a passenger feels about the cruise liner. 
1. Cruises give them value for money. It is a complete vacation in itself, consisting of all the segments of the tourism and hospitality.

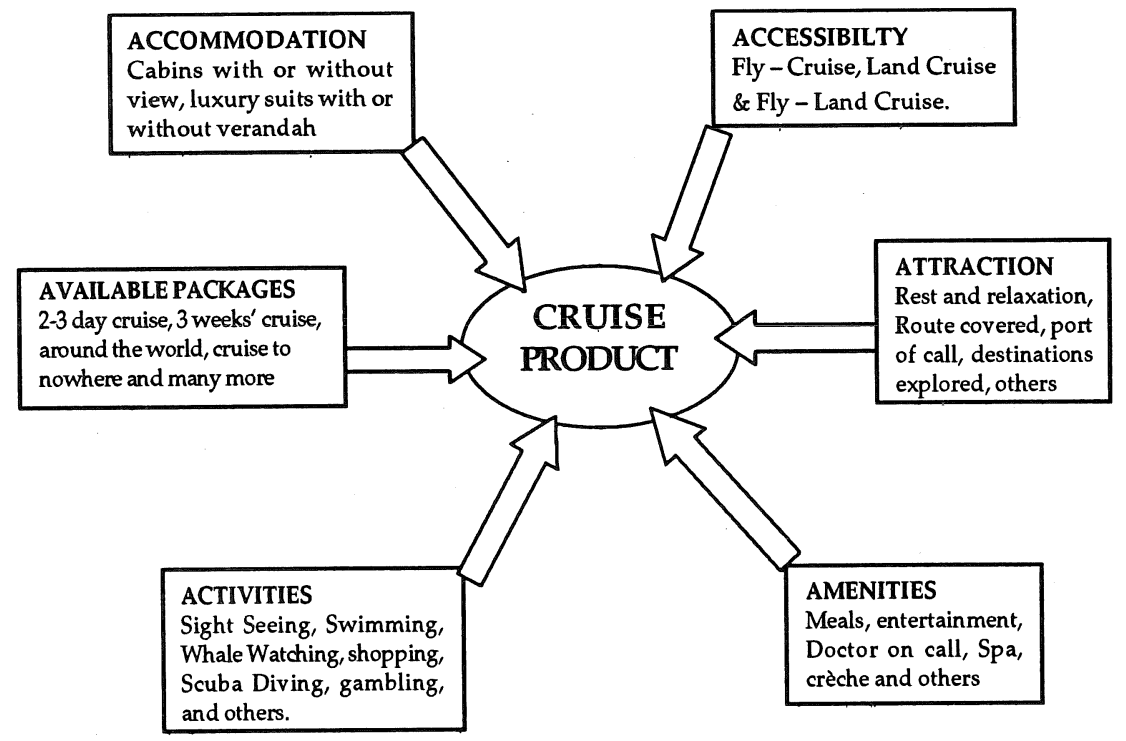

Figure 1: The Cruise Product

2. The idea of one time payment for the complete vacation - transportation, accommodation, sight seeing, entertainment and food appeals to the vacationers.

3. The idea of visiting many destinations in one vacation and that too without the trouble of packing and unpacking is very appealing.

4. Cruise vacation always had an elitist and snobbish value attached to it. Moving on the water makes Cruise all about relaxation and service.

5. The cruise liners give the tourist the freedom to do as much or as little as he wants. Other than entertainment every evening, different activity for different age groups are a great way to spend one's vacation.

6. Sight seeing, as in the case of "Passage Days" and "Rim of the Night" is a new concept for the land vacationers.

7. Provision of security and comfort whilst visiting destinations often that had a lack of developed infrastructure. (Lesley Pender). A ship has 24 hrs security plus on an average a cruise ship has 4000 smoke detectors and five firefighter teams on board (CLIA Website) 
8. One of the reasons for the popularity of the cruises in America, the largest source market for cruise passengers, is the television series called "Love Boat". Cruise Industry believes that after the series was broadcasted, the American public's interest in the cruises increased. No wonder cruise is associated with the chance to meet new people, make new friends and be idyllic \& romantic.

The vacationer's / passenger's perception about cruise is also due to the clever promotional tactics and positioning by the Cruise Companies. It started in the 1960's with the phrase "Getting there is all the fun" and after four decades this has given way to "Being here is all the fun". Over the years, steps have been taken to bridge the gap between "do not know whether I will take a cruise" and "I will take a cruise". Some of the promotional tactics are mentioned below:

1. To reach those people who considered cruises to be leisure activity of the senior citizens' and the rich \& famous, Carnival cruise liner took the first step when they declared their ship to be the "fun ship" (David w. Howell). This was done to appeal to the younger generation by introducing many on board activities like games, swimming, bingo, aerobics, crèche, etc.

2. To reach all the classes of the society cruises for a shorter time period were introduced. This allowed the prices to come down and ensured that the cruises were affordable for the common man. The 3-7 nights are very popular with the first timer cruise takers. According to the CLIA, world wide, each year nearly $40 \%-45 \%$ cruise vacationers are first timers.

3. New and exotic destinations are constantly introduced to cater to the repeat passengers / vacationers. Public interest in the cruises had led to a demand for the destinations like Antarctica as well as Greenland and the Ross Sea (W. Ritter \& C. Shafer)

4. To attract more passengers the cruise companies have started the fly/cruise. Initially this fly / cruise was started to tide over the oil price increase in the 1970s but its popularity made it a major success and it continues till date.

5. According to Morrison et al (The journal of Tourism Studies), cruising Dynamics Study was undertaken by CLIA in 1993. The figures from this study suggest that the cruise and the resort markets are not necessarily unique, but that there is a certain degree of overlap in their customer bases. It is one of the reasons why cruise liners are getting used to niche marketing. And wooing the special interest tourist by developing theme based cruises. For example 
there are special cruises catering to the honeymooners, the single and the families, all different segments of the same target market. Special cruises are also available for gay and lesbians. The need based cruises include cruises for the nature lover, music lovers, antique collectors, health conscious, sports lover and others. By specialization and concentrating on one segment of the source market each cruise liner hopes to rope in the untapped market.

6. Although other sectors like airline ticketing and hotel bookings have shifted to more user-friendly online booking. The cruise liners with the exception of a couple of companies are till date relying on the travel agents and given them an incentive ranging from $10 \%$ to $17 \%$. This ensures that this multifaceted industry keeps in touch with all its present and prospective clientele.

\section{The Indian Scenario}

The leisure market has grown in India with the increase in personal wealth. The cruise liners have made their presence felt as operations have started in the Indian Ocean and soon it will start in the Bay of Bengal, as Andhra Pradesh Government's Initiative (Express Travel \& Tourism). AP tourism is starting a cruise from Hyderabad to Colombo in a luxury cruise liner having 225 cabins. The cruise will reach Colombo via Vizag port and Rameshwaram in two days at a rate cheaper than air travel. The decision by Star Cruise, the third largest cruise company in the world (Ocean Shipping Consultants, 2004) to start operations in India reflects the growing demand for cruise vacation among the Indians. The needs of Indian vacationers are same as that of their western counterparts, such as comfort, convenience and entertainment, topped by quality service (Nishith Saxena, Country head, princess Cruises, Express Travel \& Tourism, Vol. 7).

India is expected to be the second largest source market in Asia after Japan. The Indian Market is a source of potential growth, given the changing income profile and size of population (Ocean Shipping Consultants, 2004). Yet it is seen that in India, out of estimated 5 million OBT, less than 40,000 take cruises vacation (Naresh Rawal, Star Cruises, Express Travel \& Tourism). This is probably due to:

- The lack of awareness about cruise as a vacation among the Indians

- Absence of affordable cruise along the Indian coast

- Lack of year round itinerary

Keeping in mind the fact that India is considered to become of the main source market by 2010, one does come across that many activities or awareness 
programs regarding cruise tourism in India. Things seem to be changing now. Already the cruise industry is making its presence felt in India. The Cabotage Law, wherein a ship needs to touch an international Port in between the route, has been relaxed for the next five years. E.g. Mumbai \& Goa Cruise ship would not have to touch the port of Colombo

On 29th September 2004, a high power steering committee was set up under the chairmanship of the Minister of shipping and the minister of State for Tourism as its Co - Chairman to formulate an exclusive policy for the cruise tourism (www.Pib.nic.in). First meeting was held on 14 $4^{\text {th }}$ December 2004 in which a draft policy was discussed at length. A workshop was also convened in Mumbai on $12^{\text {th }}$ Feb'05 which formulated the following plans and objectives:

1. An effort is to make India an attractive cruise tourism destination with the state of art, infrastructure and other facilities at various ports in the country. Infrastructure like dedicated terminals at the ports, rest rooms, lounges and baggage handling through conveyor belts are ensured.

2. Seven ports have been proposed to be developed as cruise shipping stations. These are Cochin in Kerala, New Mangalore in Karnataka, Marmugao in Goa, Mumbai in Maharashtra, Kolkata in West Bengal, Port Blair in Andaman \& Nicobar and Tuticorin in Tamil Nadu. Beside this, small berthing places will also be developed at various sites for small vessels.

3. Special tourism circuits pertaining to each port will also be prepared keeping in view local cultural heritage like Cochin can be linked with health circuitayurvedic massage and can be extended to backwaters, beaches and Munnar in Kerala. New Mangalore can be linked with tourism circuit of Bangalore, Bellur, Helebid and Hampi. Similarly, Mormugao can have the package, beaches of Goa and Lakshadweep. While tourists landing in Mumbai can have the destination Ajanta-Ellora and Elephanta in one package. Tuticorin can be linked with the circuit of temples.

4. The Government has also set up various working groups to sort out issues related with immigration, custom clearance, taxation, identification of infrastructure requirements and connectivity. So that the cruise visitors have hassle free movements.

5. Rail and road connectivity, air and helicopter services and metro connection are also planned for cruise ports. Chief Secretary of the concerned States has been asked to draw a blue print to be implemented within two years. 
6. The Ministry of Tourism meanwhile has decided to upgrade hotel management curriculum to include emerging new sectors like cruise tourism. Although the ministry has decided to train HR especially for the Cruise Industry, newly launched cruise liner along the Indian Coast has also recruited large number of Indians from hospitality sectors to make its operation successful.

7. The ministry is also looking taking a look at section 21 of the Merchant Shipping Act to relax registration procedures for the foreign cruise companies.

It seems like the Ministry of Shipping and Ministry of Tourism has all of a sudden awaken itself to the potential of cruise tourism and want to take steps to ensure the growth of cruise industry in India. Nevertheless, the policy makers need to consider the various impacts of cruise tourism while formulating the cruise policy.

\section{Impact Analysis}

The rapid and continuous growth of the cruise industry raises a lot of questions. The Cruise Industry is a huge revenue churner, For e.g. Carnival $\mathrm{Co}_{0}$. one of the major players had annual revenues of 3.78 billion dollars in 2004, WTO reports. Cruise Companies contributes 30 Billion to US economy in 2004 (Business Research \& Economic Advisor, BREA). Here we need to remind ourselves that the greater the revenue the greater the impact.

\section{Environmental Impacts}

It is to be understood that these huge ships will always bring about some changes in our marine environment. The ecological balance is always disturbed in big harbour where a constant ship coming is recorded. The garbage carried by the cruise ships also affects the environment of the port city. Noise pollution is a part and parcel of the life of the people living near a busy port of call.

Lesley Pender argues that cruise ships can only adversely effect our environment. She states that -

- Eco system can be disturbed due to the number of visitors and frequency of calls.

- There is always a possibility of oil seepage

- Dredge disturbs reefs and other organisms

It is not possible to say the extent of environmental impact the cruise ships will have in India and its port cities, until a research is undertaken on the same but the impacts assesses by Lesley Pender are real. 


\section{Economic Impacts}

The growth rate of the cruise industry means that four new ships joined the Cruise Industry in 2005 whereas on an average 10 - 12 ships have been added to the growing fleet of the cruise liners. This gives an idea about the tremendous number of jobs opportunity available every year. This results in both positive and negative impacts.

Some of the positive Impacts includes:

- Generation of jobs in thousands every year

- The port charges and taxes add to the harbours maintenance and development of the infrastructure.

- Along with on board jobs, port jobs are also created.

- Revenues to the travel agency for booking passengers.

While some of the negative Impacts felt are:-

- The jobs are usually not very well paid and are given to the people of Asia where the labour is cheap ( on board)

- The port calls are for very short period, therefore shopping and sight seeing do not earn much revenue for the destination if the tourist were land based

- Tourists do not spend anything on the accommodation and meals in the port of cal!

\section{Social Impacts}

Although contact between the cruises vacationers with the local hosts are for a very short time yet some social impacts are felt on both the sides. Most importantly one should remember hat less time on the shore means less interaction with the indigenous natives and no time to get into conflict with the indigenous natives

The negative impacts would include:

- Interaction only with the shopkeepers, street vendors and taxi drivers. No idea about the destination and the lifestyle of the people of the destination.

- Main ports become very crowed when ships arrive, making things difficult for the natives and a ill feeling can develop

More research is required to understand the impact of the cruise liners on the society as compared to the land based tourists 


\section{Conclusion with Suggestions}

The statistics and the trends of the past few years all bear proof to the growth of the cruise industry. Exact data about the total number of travelers / cruise passengers of India is not available. But it is said out of the 5 million OBT only 40,000 took cruises in the year 2003 , which means less than $1 \%$, only $0.8 \%$ (Naresh Rawal, Star Cruises, Express Travel \& Tourism).

The growth of this industry is causing a need to celebrate not only for the ocean / cruise liners but also for the travel agents and the job seekers. It is important for us to consider whether or not we want to be a part of this growing phenomenon. We need to formulate some ground rules and be prepared than be caught unaware. A few points to remember would be:-

- The government of India, specially the Ministry of Shipping should maintain and update weekly record of the exact number of passengers traveling to India by the Cruise Ships.

- A list of most and least favourable ports with reasons should be made.

- Make a body to look after the cruise activities in India and maybe a body within Ministry of Tourism to promote cruise as a vacation in India.

- IMO guidelines regarding the safety and security of the ships are to be followed.

- Cruise Vacations have been the root cause of destroying land based holidays in the Caribbean Islands. The Cruise Policy should be beneficial to both the cruise industry as well as to safeguard the hotel industry. Indian cruise policy needs to consider the impact of cruise tourism on the destinations land based tourism. It is a fact that the cruise ships affect the destination's resorts and hotels, yet some destinations have benefited as passengers combine their cruises with a holiday in a resort pre or post tour. (Gee, Makens and Choy).

- Cleanliness and discharge of the waste from the ships, especially in the port of call should be regulated.

- Cruise to nowhere are very popular abroad, especially around ports which ban gambling. We need to check that the cruise ships are not becoming the destinations but they are encouraging land tourism as well.

- Improve the infrastructure at the various ports and the cities near them.

- Take up an impact analysis, especially on the fragile marine ecology of our country. 
- Although every cruise liner gives training to its new recruits, no matter which department, to reap the benefits of the increasing number of jobs we need to create special training institutes and courses for the cruise recruits. Some special training to expectant employees will give them a better chance to bargain better with the cruise companies.

Time is on our side as we are starting late. And as we join this emerging segment of the tourism industry, we can learn a lot from the mistakes made by other countries in the past.

\section{Key words}

1. Port of embarkation - port where cruise begins

2. Port of call - a port / city somewhere on the ship's itinerary

3. Port of debarkation - ship's final port

4. Turnabout port - a port at which portion or all the passenger complement disembarks to be replaced by another set of passengers on their outward journey.

5. Passage Days - Sea days with no port calls but within the sight of the land. Also known as Panorama.

6. Rim of the Night - A new Destination every morning as in the Caribbean Islands.

\section{References}

1. Wigand Rilter \& Christian Schafer, Cruise Tourism - A chance of sustainability, Tourism Recreation Research, Volume 2 , Isssue \# 1

2. Express Travel and Tourism, Volume 7 Issues \&, July 2005

3. David. W. Howell, CTC, Passport - An Introduction to the Travel and Tourism Industry, South western Publishing Co, Cincinnati, Ohio, 1993 4. Cguck Y. Gee, James C. Makens, Dexter J.L. Choy, The Travel Industry, III ed, Van Nostrand
Reinhold, USA, 1997

5. Nona Starr \& Sybill Nonwood, The Traveller's world - A Dictionary of Industry \& Destination Literacy, Prentice Hall, Englewood Cliffe, New Jersey, 1996

6. Tourism, Technology \& Competitive Strategies, Poon, CAB International, 1993

7. Travel, Trade \& Transport - An Introduction, Cromwell Press, Lesley Pender, Trowbridge, Wilts,
Great Britain, 2001 


\section{Reports}

1. Annual Cruise Review 2004 by PSA, UK

2. Ocean Shipping Consultants Report on Healthy Outlook for Cruise Ships

3. Major Findings of the 2004 study on Cruise Terminal Facilities Development for Hong Kong (Study Conducted by Bermello-Ajamil \& Partners, Inc. (B\&A))

4. WTO Figures on World wide Cruise

\section{Websites}

www.brill.nl (Caribbean of the East? Global Interconnections and the South East Asian Cruise Industry, Robert E. Woods)

http://osclimited.com/releases

http://broadcastindia.com/article438930.html

http://tn.nic.in

http://Pib.nic.in/release.asp? relid $=9287$

http://Pib.nic.in/release.asp? relid $=14684$

http://Stories.Indobase.com/article_926.shtml

$\mathrm{http}: / /$ Stories.Indobase.com/article_919.shtml

$\mathrm{http}: / /$ Stories.Indobase.com/article_423.shtml

http://broadcastindia.com/article438930.html

http://broadcastindia.com/article438976.html

http://tn.gov.in/policynotes/tourism-1.htm

http://expresstravelandtourism.com/200511/lookout08.shtml

http://rediff.com/money/2005/oct/18ship.htm

http://nsnet.com/archive-1-2004-09.html

http://cruising.org/cruisenews/news. cfm?NID $=214$

$\mathrm{http}: / /$ cruising.org/planyourcruise/faqs/topten. $\mathrm{ctm}$

http://traveldailynews.com/makeof.asp?central_id=983\&permanent_id $=17$

http://echeat.com/essay.php?t=29494

http://cruises.about.com/od/cruisenews/a/041222star.htm

http://travel2.nytimes.com/2005/11/20/travel

20 prac. $\mathrm{htm}$ l? pagewanted $=1$ \&ei $=5070 \&$ en $=23327 \mathrm{~d} 0 \mathrm{~d} 94 \mathrm{~d} 29775 \&$ ex $=1139029200$

www.hydrographicsociety.org/Articles/journal/2002/103-2.htm

www.icel.org

www.jobmonkey.com/cruise/html/types_of_cruises.html

www.cruisetravel.com/types/cruises.html 
www.smarttravel.com/cruise/faq/choosing.html

www. usatourist.com/english/tips/cruises.html

www.caligtravel.com/cruises/fags. html

www.cruisebritannia.wanadoo.co.uk/UK\%20Cruise\%20Surge.htm

wuw.expresstravelandtourism.com/20020815/tradetalk1.shtml

www.nivalink.com/spicecruise/

www.hindu.com/2005/08/07/stories/2005080704091500.htm

www.astanet.com/news/releasearchive04/02_25_04.asp 